\title{
Genetic Relationships among Some Lycaenidae Butterflies as Revealed by RAPD Analysis
}

\author{
Ashish D. Tiple ${ }^{1, *}$, Arun M. Khurad ${ }^{1}$ and Sonali V. Padwad ${ }^{2}$ \\ ${ }^{1}$ Department of Zoology, Entomology Division, RTM Nagpur University Campus, Nagpur 440 \\ 033, India, and Centre for Sericulture and Biological Pest Management Research (CSBR), \\ RTM Nagpur University, Ambavihar, South Ambazari Road, Nagpur 440 022, India \\ ${ }^{2}$ Department of Biotechnology, Bioengineering Research Center (BERC), Mumbai, India
}

Received May 16, 2009; accepted July 1, 2009

\begin{abstract}
Summary RAPD analysis of 5 morphologically identical Lycaenid butterflies was carried out using 7 decamer primers. Total 114 bands produced of which 110 were polymorphic with $96.49 \%$ of similarity. Dendrograms based on similarity coefficient grouped 5 species in to two distinct clusters. Cluster-I comprised of Psuedozizeeria maha and Zizeeria karsandra while, cluster-II formed of 3 species. Cluster-II was again subdivided into two sub clusters. Sub cluster-I composed of Zizina otis and Zizula hylax, subcluster-II composed of Chilades trochylus. Similarities between these species was discussed on the basis of morphological and RAPD data.
\end{abstract}

Key words Butterfly, Genetic diversity, Lycaenidae, RAPD.

Taxonomic identification of an organism is a foremost requirement of any scientific discipline. When it concerns insects, it gets more difficult, as the differences are too minute to resolve. Morphological identification of butterflies is usually based on wing patterns (Kunte 2000, Evans 1932, Wynter Blyth 1957). Generally it is attributed to the numbers and positions of spots on the wings. The Lycaenidae is the second-largest family of butterflies consisting about 6000 species worldwide (Fiedler 1996). Approximately 521 species of Lycaenidae were described in India (Evans 1932). Butterflies belonging to Lycaenidae are very small, whose external characteristics are sufficiently uniform that it is often difficult to use classical morphological traits such as wing patterns and genitalic structure to distinguish between them. High number and small size of chromosomes in Lycaenidae to make differentiation of the species difficult at cytogenetic level (Sharma et al. 2006). Recent advances in molecular technology have greatly increased the number of techniques used in genetic studies based on the total genomic DNA analysis. Many of these techniques have been widely employed in genetic analysis of a variety of adult insects (Carvalho and Vieira 2001, Keyghobadi et al. 2005, Sofia et al. 2005). Random amplified polymorphic DNA-polymerase chain reaction (RAPD-PCR) using a random primers amplifies many regions of genomic DNA (Williams et al. 1990). Polymerase chain reaction derived markers with non-specific primers have been exceedingly popular since they do not request sequence information from target species. RAPDs are especially suited for situations where little or no molecular genetics research has been conducted previously and it is true for the majority of our wild species (Nybom 2004).

RAPD has been successfully applied to study the genetic structure of endangered populations (Vandewoestijne and Baguette 2002), interspecific study (Sharma et al. 2006) and gene flow between populations (Hoole et al. 1999). Two species of butterflies belonging to the family Pieridae have been characterized at molecular level by Sharma et al. (2003). Although many studies on morphological and ecological aspects of several species of Lycaenidae are available, very little is known about their molecular genetics which, is true about most of the Indian species from this family. This

\footnotetext{
* Corresponding author, e-mail: ashishdtiple@yahoo.co.in
} 
paper described the fisibility of RAPD in discriminating five morphologically identical species of family Lycaenidae and the genetic similarities in these species.

Materials and methods

\section{Butterflies}

Five adult individuals of each Pale grass blue (Psuedozizeeria maha), Dark grass blue (Zizeeria karsandra), Lesser grass blue (Zizina otis), Tiny grass blue (Zizula hylax) and Eastern grass jewel (Chilades pulti) were collected from different sites in and around Nagpur city (India). DNA from 5 individuals of each species was extracted and pooled.

\section{Extraction of DNA}

Genomic DNA was extracted from the legs of freshly collected each individual by Qiagen DNeasy ${ }^{\circledR}$ extraction kit following manufacturer's instructions (Westburg b. v; Netherlands). The concentration of DNA was determined by spectrophotometric method using UV visible scanning spectrophotometer.

\section{Random amplified polymorphic DNAs (RAPDs)}

About 10 random primers were used in a single primer PCR. The PCR reaction mixture $(25 \mu \mathrm{l})$ contained $25-50 \mathrm{ng}$ of DNA, $1.25 \mathrm{U}$ Taq DNA polymerase enzyme (Fermentas, USA), $0.4 \mu \mathrm{M}$ each dNTPs $(10 \mathrm{mM}), 2.5 \mathrm{mM} \mathrm{MgCl} 2(15 \mathrm{mM}), 1 \mathrm{X}$ Taq DNA polymerase buffer supplied with enzyme and $0.4 \mu \mathrm{M}$ decamer primer (Operon, USA). The DNA was amplified in a programmable thermocycler (T Personal Biometra, GMBh, Gottingen, Germany) using the following conditions: Initial denaturation at $94^{\circ} \mathrm{C}$ for $5 \mathrm{~min}$, followed by 45 cycles denaturation at $94^{\circ} \mathrm{C}$ for $1 \mathrm{~min}$, annealing of primer at $38^{\circ} \mathrm{C}$ for $1 \mathrm{~min}$, and extending primer at $72^{\circ} \mathrm{C}$ for $3 \mathrm{~min}$ and final extension at $72{ }^{\circ} \mathrm{C}$ for $7 \mathrm{~min}$. The amplified PCR products were fractionated on $1.2 \%$ agarose gel using $1 \mathrm{X}$ TAE buffer containing $5 \mu \mathrm{g} / \mathrm{ml}$ ethidium bromide. Gel was photographed on Gel documentation system (Alpha Innotech, USA).

For RAPD analysis data was scored as ' 1 ' for the presence and ' 0 ' for the absence of band of each species. The similarity matrix was prepared by using Nei and Li formula (1979). The average of similarity matrix was used to generate a tree for cluster analysis by UPGMA (Unweighted Pair Group Method with Arithmetic Average) method using NTSYS 2.1 (Rohlf 1999). All computations were performed with appropriate procedures of NTSYS-pc version 2.1.

\section{Results and discussion}

Of all the 10 decamer RADP primers used, 7 primers (Table 1) produced reproducible banding

Table 1. RAPD primers, their sequences and \% polymorphism

\begin{tabular}{|c|c|c|c|c|c|c|}
\hline S.N. & Primer & Seq $5^{\prime}$ to $3^{\prime}$ & Total bands & $\begin{array}{l}\text { Polymorphic } \\
\text { bands }\end{array}$ & $\begin{array}{l}\text { Monomorphic } \\
\text { bands }\end{array}$ & $\begin{array}{c}\text { Polymorphism } \\
(\%)\end{array}$ \\
\hline 13 & OPAP-1 & AACTGGCCCC & 13 & 13 & 00 & 100 \\
\hline 14 & OPAP-4 & CTCTTGGGCT & 17 & 16 & 01 & 94.11 \\
\hline 15 & OPAP-5 & GACTTCAGGG & 21 & 20 & 01 & 95.23 \\
\hline 16 & OPAP-6 & GTCACGTCTC & 22 & 22 & 00 & 100 \\
\hline 17 & OPAP-8 & ACCCCCACAC & 12 & 11 & 01 & 91.66 \\
\hline 18 & OPAP-10 & CTGGCTTCTC & 12 & 11 & 01 & 91.66 \\
\hline 19 & OPW-1 & CTCAGTGTCC & 12 & 12 & 0 & 100 \\
\hline 32 & Total & & 114 & 110 & 04 & 96.49 \\
\hline
\end{tabular}


pattern and were selected for analysis. A Total of 114 bands were produced of which 110 were polymorphic, whereas 4 were monomorphic (Fig. 1). On average, 16.28 bands per primer were scored and the average percentage polymorphism was $96.49 \%$. Primer OPAP- 6 produced a maximum of 22 bands, while primer OPAP-8, OPAP-10 and OPW-1 produced a minimum of 12 bands each. In all 3 primers (OPAP-1, OPAP-6, and OPW-1) produced 100\% polymorphism, whereas primers OPAP-8 and OPAP-10 produced a minimum of $91.66 \%$ polymorphism each. A similarity matrix, (Table 2) according to Nei and Li (1979), formula revealed the highest (0.647) similarity coefficient between $Z$. otis and Z. hylax, whereas the minimum (0.207) similarity coefficient was observed between $P$. maha and C. pulti. Dendrogram generated (Fig. 2) from average similarity coefficient of 7 primers grouped 5 Lycaenidae species into two distinct clusters. Cluster-I comprised of two species viz. $P$.

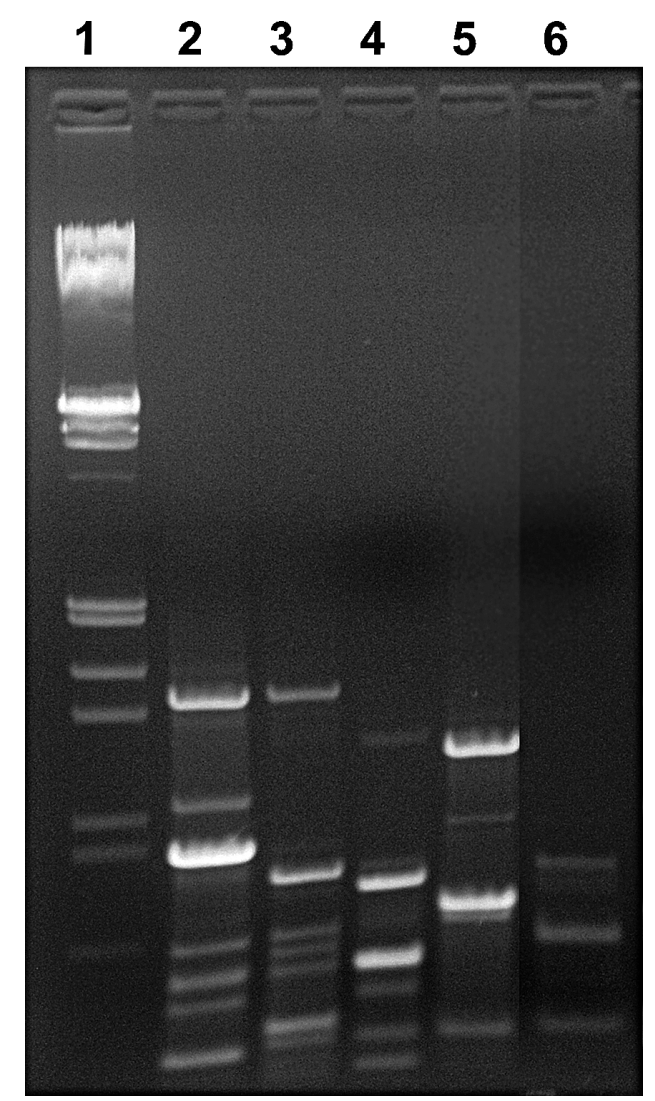

Fig. 1. RAPD banding pattern with primer OPAP-4. Lane 1 Lambda DNA/EcoRI + HindIII, Lane 2 Psuedozizeeria maha, Lane 3 Zizeeria karsandra, Lane 4 Zizina otis, Lane 5 Zizula hylax, Lane 5 Chilades pulti. maha and Z. karsandra, while cluster-II consisted of 3 species. Cluster-II further subdivided into two sub clusters, subcluster-I consisting of Z. otis and Z. hylax and subcluster-II C. pulti. The dendrograms showed more similarities with morphological differentiation of these 5 species. A cluster of $P$. maha and Z. karsandra species exhibited similarities in terms of their rounded spots on upper side of wings but the spots were faint in former and dark in latter. The clustering of Lesser grass blue (Z. otis) and Tiny grass blue (Z. hylax) was also justified by spot positions and size. The upper side spots on former are rounded and not very dark, whereas the spots in latter are narrow and fine. The isolated position of $C$. pulti on dendrograms was due to presence of metallic orange-crowned spots at the margin of upper wing which are totally different from other 4 species (Kunte 2000). RAPD-PCR revealed band patterns, which were species specific and can be used in rapid diagnosis of species. Earlier RAPD-markers were widely used to study phylogenetics in mites and ticks (Cruickshank 2002), to differentiate populations of insects (Lynch and Milligan 1994), and species and biotypes (Lima et al. 2000). Since no DNA sequence information is required to perform RAPDs, it can be widely used for species differentiation (Sharma et al. 2006).

Table 2. Similarity matrix of five Lycaenidae species based on RAPD data

\begin{tabular}{lccccc}
\hline \hline & $\begin{array}{l}\text { Psuedozizeeria } \\
\text { maha }\end{array}$ & $\begin{array}{l}\text { Zizeeria } \\
\text { karsandra }\end{array}$ & $\begin{array}{l}\text { Zizina } \\
\text { otis }\end{array}$ & $\begin{array}{l}\text { Zizula } \\
\text { hylax }\end{array}$ & $\begin{array}{l}\text { Chilades } \\
\text { pulti }\end{array}$ \\
\hline Psuedozizeeria maha & 1 & & & & \\
Zizeeria karsandra & 0.620 & 1 & 1 & & 1 \\
Zizina otis & 0.511 & 0.597 & 0.647 & 0.383 & 1 \\
Zizula hylax & 0.483 & 0.476 & 0.262 & & \\
Chilades pulti & 0.207 & 0.232 & & & \\
\hline
\end{tabular}




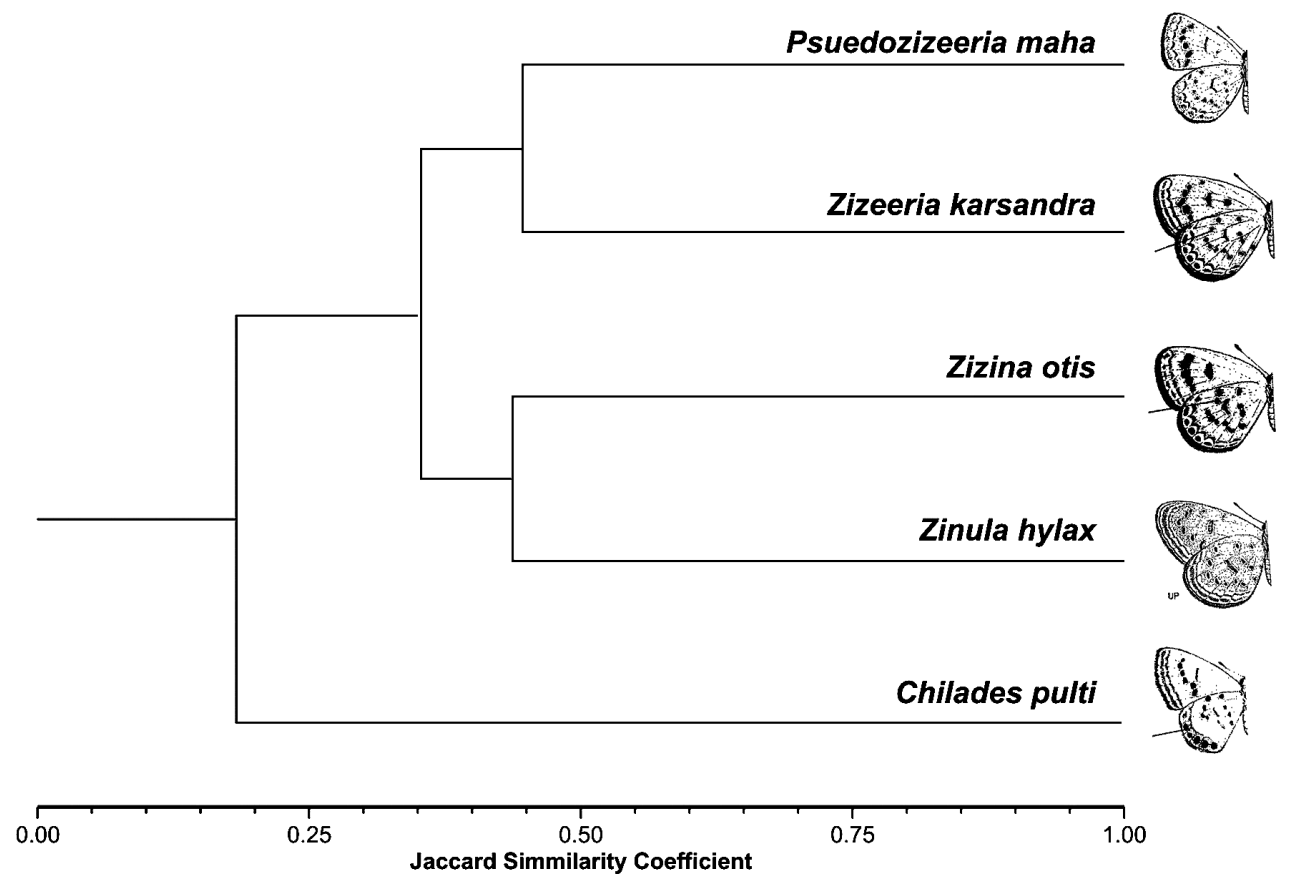

Fig. 2. Dendrogram of 5 Lycaenidae species based on RAPD data.

Thus it can be concluded that RAPD could be utilized as a fast and effective method in support of morphological characters for the identification or discrimination of butterfly species where sole external character creates confusion in identification.

\section{Acknowledgements}

We are grateful to Mr. Vishal P. Deshmukh, Department of Botany, SGB Amravati University Amravati for his kind help. We are also thankful to Dr. Avinash Upadhay, Head of Department of Biotechnology, Hislop College, Nagpur and Dr. A. D. Choudary, Professor, Department of Botany, Director BCUD, RTM Nagpur University Nagpur for availing PCR facilities, and Dr. K Kunte for their comments on earlier drafts. Our grateful thanks to anonymous referees for their comments.

\section{References}

Carvalho, A. O. R. and Vieira, L. G. E. 2001. Determinação das condições ótimas para análises de PCR-RAPD em Atta sexdens rubropilosa Forel (Hymenopera: Formicidae). Neotrop. Entomol. 30: 593-600.

Cruickshank, R. H. 2002. Molecular markers for the phylogenetics of mites and ticks. System. Appl. Acarol. 7: 3-14.

Evans, W. H. 1932. The identification of Indian butterflies. Bombay Nat. Hist. Soc. Bombay.

Fiedler, K. 1996. Host-plant relationships of lycaenid butterflies: large-scale patterns, interactions with plant chemistry, and mutualism with ants. Ento. Exp. Appl. 80: 259-267.

Hoole, J. C., Joyce, D. A. and Pullin, A. S. 1999. Estimates of gene flow between populations of the swallowtail butterfly Papilio machaon in Broadland, UK and implications for conservation. Biol. Conserv. 89: 293-299.

Keyghobadi, N., J. Roland and C. Strobeck. 2005. Genetic differentiation and gene flow among populations of the alpine butterfly, Parnassius smintheus, vary with landscape connectivity. Mol. Ecol. 14: 1897-1909.

Kunte, K. 2000. Butterflies of Peninsular India. Universities Press (Hyderabad) and Indian Academy of Sciences (Bangalore).

Lima, L. H., Navia, C. D., Inglis, P., de Oliveira, W. 2000. Survey of Bemisia tabaci (Gennadius) (Hemiptera: Aleyrodidae) 
biotypes in Brazil using RAPD markers. Genet. Mol. Biol. 23: 781-785.

Lynch, M. and Milligan, B. G. 1994. Analysis of population genetic structure with RAPD markers. Mol. Ecol. 3: 91-99.

Nei, M. and Li, W. 1979. Mathematical model for studying genetic variation in terms of restriction endonucleases. Proc. Natl. Acad. Sci. 76: 5269-5273.

Nybom, H. 2004. Comparison of different nuclear DNA markers for estimating intraspecific genetic diversity in plants. Mol. Ecol. 13: 1143-1155.

Rohlf, F. J. 1999. NTSYS-PC numerical taxonomy and multivariate analysis system. Version 2.1 Exeter Software, Setauket, NY.

Sharma, V. L, Bhatia, S., Gill, T. K., Badran, A. A., Kumari, M., Singh, J. J. and Sobti, R. C. 2006. Molecular characterization of two species of butterflies (Lepidoptera: Insecta) through RAPD-PCR technique. Cytologia 71: 81-85.

-, Gill, T. K., Sharma, S., Badran, A. L. A. and Sobit, R. C. 2003. RAPD-PCR in two species of Catopsilia (Pieris, Lepidoptera). Caryologia 56: 219-222.

Sofia, S. H., Paula, F. M., Santos, A. M., Almeida, F. S. and Sodré, L. M. K. 2005. Genetic structure analysis of Eufriesea violacea (Hymenoptera, Apidae) populations from southern Brazilian Atlantic Forest remnants. Genet. Mol. Biol. 28: 479-484.

Vandewoestijne, S. and Baguette, M. 2002. The genetic structure of endangered populations in the Cranberry Fritillary, Boloria aquilonaris (Lepidoptera, Nymphalidae): RAPDs vs allozymes. Heredity 89: 439-445.

Williams, J. G. K., Kubelik, A. R., Livak, K. J. Rafalski, J. A. and Tingey, S. V. 1990. DNA polymorphisms amplified by arbitrary primers are useful as genetic markers. Nucl. Acids Res. 18: 6531-6535.

Wynter-Blyth, M. A. 1957. Butterflies of the Indian Region. Bombay Nat. Hist. Soc. Bombay. p. 523. 